\title{
Impact of KVK Trainings on Promotion of Backyard Poultry Farming in Bidar District
}

\author{
Akshaykumar $^{1 *}$, N. M. Sunilkumar ${ }^{1}$, Ningdalli Mallikarjun ${ }^{1}{\text { and } \text { Vidyasagar }^{2}}^{2}$ \\ ${ }^{1}$ ICAR-Krishi Vigyan Kendra, Bidar, Karnataka, India \\ ${ }^{2}$ Livestock production and Management) Veterinary College, Bidar, Karnataka, India \\ *Corresponding author
}

\section{Keywords}

Backyard Poultry, Training, KVK, Adoption Level, Small\& Marginal Farmer

\section{Article Info}

Accepted:

12 January 2021

Available Online:

10 February 2021
ICAR- Krishi Vigyan Kendra, Bidar conducting various training programmes to farmers to know the impact of trainings on scientific method of backyard poultry farming among small and marginal poultry farmers participated in ICAR- KVK Bidar for training programme. Collection of data regarding gain in knowledge and adopted level about improved poultry science technologies in backyard poultry farming were recorded before and after trainings. Agriculture is said to be the backbone of Indian economy and allied agricultural sector are main source of job opportunity and also provides food and nutritional security of the Indian population. Among various agriculture and allied farming, Poultry farming is one of the most efficient components of the farmer's economy as it provides eggs, meat, feathers and manures with small capital investment and fewer workforces. The beneficiary of backyard poultry farming training programmes gained highest knowledge about new breed $(85.00 \%)$ fallowed by balanced poultry feed and lime stone grit both $(82.50 \%)$ and the least scavenging habit(55.00\%). The present study aimd to evaluate the impact of training on the livelihood of backyard poultry farming. The overall adoption percentage by the farmers indicated that training had significant impact on uptake of new technologies.

\section{Introduction}

The poultry farming is a very old practice in India since 5000 years it is being practiced and its contribution is high for rural Indian economy. India is the fifth largest producer of eggs and ninth largest producer of poultry meat amongst all the countries. The unorganized sector of poultry industry is contributing 30 per cent of the total output and the rest 70 per cent in organized sector. Backyard poultry farming play an important role in the economic development of the country (Nath et al., 2012). Training is an integral and crucial input for the human resources development in all walks of life, be it agriculture, poultry rearing, animal husbandry, fisheries or any other field for bringing out desirable changes in human behavior (Biswas et al., 2008). In recent years, for sustained rural livelihood of the rural youth backyard poultry production has playing a very important role. In this farming, birds are kept in low-input and low output 
system and can easily be managed by rural women and children of the households. The local native chicken varieties adopted in free range backyard condition for centuries contribute about 11 percent of total egg production in India (Kumaresan et al., 2008) and the role of backyard poultry farming in sustaining and enhancing poor people's livelihoods in developing countries is well recognized among the development community (Ahuja et al., 2008).

Among traditional farmers, backyard poultry is a handy enterprise with low-cost initial investment, but high economic return along with guarantee for improving protein deficiency among the poor. The concept of training programmes in scientific method of Backyard poultry farming through ICARKVK Bidar substantially due to greater demand for improved poultry science technology by the farmers. Poultry population plays an important role in the national economy and socio-economic development of the landless, small and marginal farmers by supplementing family income and generating employment.

Most of the farmers are rearing poultry under traditional pattern and lack of scientific knowledge. Therefore, the present study was undertaken with the following specific objective to study the impact of training imparted by ICAR-Krishi Vigyan Kendra, Bidar on scientific method of backyard poultry farming and feeding practices.

\section{Materials and Methods}

Therefore a present study was undertaken at Kalyan Karnataka (H-K) region ICAR-Krishi Vigyan Kendra, Bidar the poultry farmers from different villages of Bidar district viz., Jamgi, Janthi, Gundur, Nandagaon, Maharaj wadi, Gunnnalli, Bemalkheda and Basavakalyan of Karnataka. The on-campus training programmes was conducted to 40 beneficiary farmers on feeding, breeding and disease management under scientific poultry farming at ICAR-KVK, Bidar. Participants took interest and eagerly participated in training programme. Pre-determined questionnaire supplied to trainees (rural youth farmers and farm women) participated in trainings organized at $\mathrm{KVK}$ to know and record their experiences. To confirm their adoption regarding scientific method of backyard poultry farming at farm level the data were collected through personal contacts with the help of well structured interview schedule.

A set of questions related to the topic of training was prepared and it was given to the participants before starting of the training programme and same questions was again given at the end of the training programmes. Two sets of scores was obtained ie. Pre evaluation score and post evaluation score and Knowledge gain was calculated by using the formula.

Knowledge gain $(\%)=($ Post evaluation score - Pre evaluation score)/ Total score

Percent of knowledge gain and adoption level were obtained for the individual training and presented in table. The data collected were processed, tabulated, classified and analyzed in terms of percentage in the light of objectives of the study. Total practices were selected to find out the extent of knowledge and adoption of scientific method of backyard poultry farming.

\section{Results and Discussion}

Extent of Gain in Knowledge about scientific practices in backyard poultry

The gain in knowledge by the respondents about scientific methods of backyard poultry 
farming and azolla feeding was measured in terms of percentage. The data regarding gain in knowledge about scientific method of backyard poultry farming and feeding technologies were recorded under two heads i.e. knowledge before training and after training.

Table.1 Distribution of respondents according to Gain in knowledge about scientific method of backyard poultry farming and the feeding technology $(n=40)$

\begin{tabular}{|l|l|c|c|c|c|}
\hline Sl no & Technologies & \multicolumn{2}{|c|}{ Gain in knowledge( no) } & \multicolumn{2}{c|}{ Gain in knowledge( \%) } \\
\cline { 3 - 6 } & & $\begin{array}{l}\text { Before } \\
\text { training }\end{array}$ & $\begin{array}{l}\text { After } \\
\text { training }\end{array}$ & Before training & After training \\
\hline $\mathbf{1}$ & Housing System & 15 & 30 & 37.50 & 75.00 \\
\hline $\mathbf{2}$ & $\begin{array}{l}\text { New breed ( Giriraj/ } \\
\text { Swarnadhara) }\end{array}$ & 20 & 34 & 50.00 & 85.00 \\
\hline $\mathbf{3}$ & Balanced poultry feed & 10 & 33 & 25.00 & 82.50 \\
\hline $\mathbf{4}$ & Vaccination(F1) & 18 & 30 & 45.00 & 75.00 \\
\hline $\mathbf{5}$ & Lime stone grit feeding & 15 & 33 & 37.50 & 82.50 \\
\hline $\mathbf{6}$ & Scavinging habit & 13 & 22 & 32.50 & 55.00 \\
\hline $\mathbf{7}$ & Azolla feeding & 2 & 25 & 5.00 & 62.50 \\
\hline
\end{tabular}

Table.2 Distribution of respondents according to adoption about scientific method of backyard poultry farming and the feeding technology $(n=40)$

\begin{tabular}{|c|l|c|c|c|}
\hline SI no & \multicolumn{1}{|c|}{ Technologies } & \multicolumn{2}{|c|}{ Gain in knowledge( \%) } & $\begin{array}{c}\text { Adoption level increase } \\
\text { (\%) after training }\end{array}$ \\
\cline { 3 - 5 } & & Before training & 75.00 & 37.50 \\
\hline $\mathbf{1}$ & Housing System & 37.50 & 85.00 & 35.00 \\
\hline $\mathbf{2}$ & $\begin{array}{l}\text { New breed (Giriraj/ } \\
\text { Swarnadhara) }\end{array}$ & 50.00 & 82.50 & 57.50 \\
\hline $\mathbf{3}$ & Balanced poultry feed & 25.00 & 75.00 & 30.00 \\
\hline $\mathbf{4}$ & Vaccination(F1) & 45.00 & 82.50 & 45.00 \\
\hline $\mathbf{5}$ & Lime stone grit feeding & 37.50 & 55.00 & 22.50 \\
\hline $\mathbf{6}$ & Scavinging habit & 32.50 & 62.50 & 57.50 \\
\hline $\mathbf{7}$ & Azolla feeding & 5.00 & & \\
\hline
\end{tabular}

The data presented in the Table 1 with regards to the level of gain in knowledge revealed that, the beneficiary farmers of backyard poultry farming training programmes gained highest knowledge about new breed(85.00\%).

It was also found that a majority of the backyard poultry farmers gained highest knowledge about balanced poultry feed and lime stone grit $(82.50 \%)$ followed by housing system (semi intensive and intensive) and vaccination (F-1) (75.00\%), azolla feeding
(62.50\%) and Scavenging habit(55.00\%). The findings are in confirmation with the results of the research studies conducted by Verma $e t$ al., (2018) revealed that training has a definite impact on the knowledge level of the respondents.

The results were in agreement with Biswas $e t$ al., (2008) who reported that the effect of training on backyard poultry farming practices and indicated that backyard poultry training programme had a significant 
difference in knowledge of respondents in scientific practices like feeding and vaccination.

\section{Extent of Adoption of scientific practices in backyard poultry}

With regards to the level of adoption, beneficiary farmers of backyard poultry farming training programmes the data presented in the Table 2 revealed that before training very few farmers were following the scientific method of backyard poultry farming and azolla feeding. Like housing system (Semi intensive, Intensive) $37.50 \%$, new variety breed $50.00 \%$, balanced poultry feed $25.00 \%$, vaccination (F1) $45.00 \%$, lime stone grit $37.50 \%$, grazing $32.50 \%$ and very less of the farmers were adopted azolla feeding $(5.00 \%)$ before acquiring training.

Whereas, after attending training programme the adoption level increased in balanced poultry feeding and Azolla feeding 57.50\% each, lime stone grit $45.00 \%$, housing system $37.50 \%$, new variety breed $35.00 \%$, vaccination (F- 1), 30.00\% and Scavenging $22.50 \%$ respectively.

These findings are also in support with Verma, et al., (2018), who concluded that training, had positive impact on the farmer's perception and performance.

In present study it was concluded that the training program has a tremendous impact on the farmers on adoption of scientific method of backyard poultry farming. Among different parameters balanced poultry feeding and azolla feeding had highest level of adoption percentage $(57.50 \%)$ and least adoption percentage in scavinging habit practice $(22.50 \%)$ was observed. Azolla can be considered as part of feed replacing $25 \%$ of balanced feed. The overall adoption percentage by the farmers indicated that training had a significant impact in uptake of new technologies thereby increasing their livelihood with renewed income. The training imparted to farmers increased the awareness about new technologies among the beneficiaries and increased their knowledge. As most of the poor and marginal farmers have very limited capital assets and they mostly depend on poultry farming for their livelihoods. Therefore it is very much.

\section{References}

Biswas, S., A.Sarkar and A.Goswami.Impact of KVK training on advance dairy farming practices (AFDPS) in changing knowledge and attitude of Prani Bandhu J. Dairying Foods Home Sci 2008. 27(1): P43-46.

Kumaresan A, Bujarbaruah KM, Pathak KA Analysis of village chicken production system and performance of improved dual purpose chicken under a subtropical hill agro-ecosystem in India. Trop Anim Health Prod 2008 :40,395402.

Nath BG, Pathak PK, Mohanty AK. Scientific backyard poultry rearing technologies: an approach to awareness and adoption of technology for livelihood development of rural farmers in Sikkim, India. Russian Journal of Agricultural and Socio Economic Sciences. 2013;22(10).

Verma, L.C.; R. Nayak. S.K. Sachan, Rudra P. and Singh, R. K. Anand (2018). Impact of KVK trainings in promotion of scientific dairy farming in Azamgarhdistrict. Progressive research - An International journal, Vol. 13, (Special). 


\section{How to cite this article:}

Akshaykumar, N. M. Sunilkumar, Ningdalli Mallikarjun and Vidyasagar. 2021. Impact of KVK Trainings on Promotion of Backyard Poultry Farming in Bidar District. Int.J.Curr.Microbiol.App.Sci. 10(02): 129-133. doi: https://doi.org/10.20546/ijcmas.2021.1002.016 